\title{
Characterization of the protozoan parasite Marteilia refringens infecting the dwarf oyster Ostrea stentina in Tunisia
}

\author{
Refka Elgharsalli ${ }^{\mathrm{a}, *}$, Nejla Aloui-Bejaoui ${ }^{\mathrm{a}}$, Hedi salah $^{\mathrm{a}}$, Bruno Chollet ${ }^{\mathrm{b}}$, Jean-Pierre Joly ${ }^{\mathrm{b}}$, \\ Maeva Robert ${ }^{b}$, Yann Couraleau ${ }^{b}$, Isabelle Arzul ${ }^{b, *}$ \\ a Institut National Agronomique de Tunisie, 43, Avenue Charles Nicolle, 1082 Tunis, Tunisia \\ b IFREMER, Laboratoire de Génétique et Pathologie, Avenue de Mus de Loup, 17390 La, Tremblade, France \\ *: Corresponding authors : Refka Elgharsalli, email address : refkagr@yahoo.fr ; Isabelle Arzul
}

\begin{abstract}
:
Marteilia refringens is a protozoan parasite recognized as a significant pathogen of the European flat oyster Ostrea edulis. The life cycle of this species is still poorly known, although there is evidence of the need for intermediate host(s). In the present study, we have used molecular approaches to identify this parasite in samples of the dwarf oyster Ostrea stentina after reports of massive mortality along the Tunisian coasts. In 2009 we evaluated the status of $O$. stentina from Monastir and checked if there was an infection with $M$. refringens, using polymerase chain reaction assays. Of the 103 tested $O$. stentina, 85 were PCR-positive using a Marteilia genus-specific assay. Additional assays were subsequently carried out on some samples collected in 2010 in Monastir and processed for histology, transmission electron microscopy and complementary molecular analyses. PCR was carried out to amplify the IGS and ITS regions. Histological and transmission electron microscopy analyses allowed us to confirm the presence of this parasite in the digestive gland tissue of $O$. stentina and to characterize it at the ultrastructural level. This is the first record of the occurrence of $M$. refringens in the oyster $O$. stentina along the Tunisian coasts.
\end{abstract}

\section{Graphical abstract:}

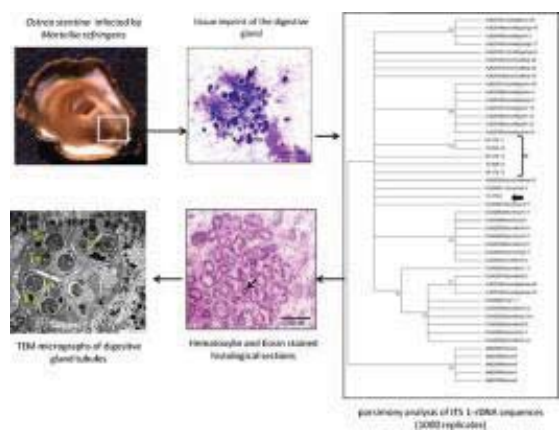

\section{Highlights}

Molecular analysis, histology and TEM were used for the detection of Marteilia refringens. phylogenetic affinity of ITS-1 sequences was determined. The results analyses allowed us to confirm the presence of parasite in Ostrea stentina. This is the first record of $M$. refringens in a new host species in a new site, Tunisia.

Keywords: Marteilia refringens ; Molecular diagnosis ; IGS ; ITS ; Transmission electron microscopy ; Ostrea stentina 


\section{Introduction}

Marteilia refringens is a protozoan parasite belonging to the phylum Cercozoa and order Paramyxida (Cavalier-Smith, 1998; Cavalier-Smith and Chao, 2003; Feist et al., 2009) which affects commercially important bivalve species including the flat oyster Ostrea edulis, the mussels Mytilus edulis, and Mytilus galloprovincialis (Grizel et al., 1974a,b ; Le Roux etal., 2001, Lopez-Flores et al., 2004, Novoa et al., 2005; Robledo et al., 1995a; Villalba et al.,1993b). It has been responsible for recurrent mass mortalities of flat oysters in Europe over the last four decades (Grizel et al, 1974a; Berthe et al, 2004) and has thus been recognized by the World Organization for Animal Health as a significant pathogens of bivalve mollusks (OIE.Cod, 2011).

Based on ultrastructural characteristics and host specificity two Marteilia species, $M$. refringens infecting oysters and $M$. maurini infecting mussels were identified in Europe (Grizel et al. 1974b; Perkins, 1976; Figueras \& Montes, 1988). However, subsequent ultrastructural examination concluded that these characteristics were invalid to distinguish both parasite species (Longshaw et al. 2001). Further studies based on the ITS1 region showed dimorphism that allowed identification of two types: O preferentially detected in oysters and M preferentially detected in mussels (Le Roux et al., 2001; Novoa et al., 2005; Balseiro et al., 2007). Data subsequently obtained on the IGS region suggested that both types constitute two different strains of the species M. refringens (Lopez-Flores et al., 2004).

Unidentified Marteilia, were observed in many species naturally present or immerged in the geographic range of the parasite $M$. refringens such as the oysters Ostrea chilensis (Grizel et al., 1983), Ostrea angasi (Bougrier et al., 1986) and Ostrea puelchana (Pascual et al., 1991) and Crassostrea virginica (Renault et al., 1995), the cockle Cardium edule (Comps et al., 1975), the clams Ruditapes decussatus (Villalba et al., 1993), Tapes rhombïdes, Tapes pullastra (Poder et al., 1983), Ensis minor, Ensis siliqua (Ceschia et al., 2001), Scrobicularia piperata (Comps, 1983;1985) and Saccostrea cucullata (Comps, 1976). Unidentified Marteilia have also been observed in manila clams $R$. philippinarum in Japan (Itoh et al. 2005).

Recent studies have reported the presence of Marteilia refringens in clam species, Solen marginatus (Lopez- Flores et al, 2008a), Chamelea gallina (Lopez-Flores et al., 2008b) and the mussel Xenostrobus securis (Pascual et al., 2010) suggesting that these species are 
susceptible to infection with $M$. refringens according to the definition. A new Marteilia sp. Type $\mathrm{C}$ has also been detected and characterized from cockles Cerastoderma edule in the Spanish Mediterranean coast (Carrasco et al. 2011; Carrasco et al. 2012).

These numerous observations suggest that Marteilia refringens has a wide host range. However, it is also hypothesized that intermediate hosts including some copepod species involved in the life cycle of the parasite. Indeed, direct transmission from infected to naïve bivalves is not possible and experimental studies have shown that it is possible to infect non infected copepod Paracartia grani with infected flat oysters or mussels (Audemard et al., 2001; Carrasco et al., 2008). Unfortunately transmission assays from infected copepods to naïve bivalves had never been successful. Moreover, depending on the investigated infected sites, it seems that different zooplancton species could be infected or vector of the parasites. In the Claire system in France, the copepod P. grani was found infected with M. refringens (Audemard et al., 2002) while in Delta del Ebro in Spain, other zooplanctonic species like the Acartia discaudata, A. clausi, A. italic, Oithona sp.; and an indeterminate Harpacticoid species, Euterpina acutifrons were found positive by PCR. These results suggest that the parasite $M$. refringens might present different life cycle including different definitive and possibly intermediate hosts depending on the ecosystems where it occurs.

Ostrea stentina (Payraudeau, 1826), also known as the Provence oyster or dwarf oyster occurrs in the Mediterranean Basin (Ranson, 1967), but also along African and Atlantic coasts, possibly even as far as south Africa (Carriker and Gaffney., 1996; Lapegue et al., 2006). Ostrea stentina has a slight economic potential due to its small shell size. It lives in shallow subtidal waters, in tropical and temperate seas (Harry, 1985). In Tunisia, O. stentina is distributed over the northern and the eastern coasts (Seurat, 1934; Lapegue et al., 2006). The high density of the O. stentina population observed in 2006 was probably related to its intense reproductive cycle (Elgharsalli \& Aloui-Bejaoui, 2011).

However in 2007, the Tunisian populations of O. stentina greatly decreased following reports of mass mortalities. In order to investigate possible causes of these mortalities, histological examination and molecular tests of $O$. stentina from Hammamet, were performed in June 2007. This preliminary investigation resulted in the detection and characterization of a relatively low prevalence (10.6\%) of parasites belonging to the Bonamia exitiosa group (Hill 
et al., 2010), suggesting that other factors or pathogens could be responsible for the mass mortalities observed along Tunisia coasts. In this context, flat oyster $O$. stentina were newly collected in Monastir in 2009. Samples were screened by PCR for the detection of parasites of the genus Bonamia and for the detection of Marteilia refringens. Positive results were obtained with both PCR assays but prevalence of M.refringens appeared higher $(87.8 \%)$ (unpublished data).

Following the detection of Marteilia refringens by PCR in a new host species Ostrea stentina in a new location, Tunisia, it was necessary to better characterize the parasite in order to complete and confirm these first results. Additional molecular analyses were carried out on samples collected in 2009 and oysters were collected again in 2010 in Monastir and processed in order to perform histology, transmission electron microscopy and molecular analysis.

\section{Materials and methods}

\subsection{Study area}

The Stah Jeber port is a semi-enclosed artificial basin located in the south-eastern Mediterranean Sea, more precisely in the Monastir Bay on the east coast of Tunisia $\left(35^{\circ} 45^{\prime}\right.$ 29 " $\mathrm{N} ; 10^{\circ} 50^{\prime} 13^{\prime \prime}$ E, Figure 1). The mean depth is $3.5 \mathrm{~m}$ with a maximum of $5 \mathrm{~m}$ and a surface area of about $227.800 \mathrm{~m}^{2}$. This bay displays a wide biodiversity and includes at least 44 different species among which Bittium reticulatum (Gasteropod), Pinctada radiate (Bivalve), Pinna nobilis (Bivalve), Sabellaria alveolata (Annelids) (Ikram et al., 2007).

\subsection{Samples}

In 2009, thirty specimens of Ostrea stentina were sampled, seasonally (February, March, June and October), in Stah Jeber port from shallow areas at a depth of between $1.5 \mathrm{~m}$ and $5 \mathrm{~m}$. Whole oyster soft tissue was dissected, then frozen and stored in liquid nitrogen. In May 2010, 20 specimens were collected at the Stah Jeber port. These oysters were screened by digestive gland imprints and positive oysters were selected for further characterization.

\subsection{Digestive gland imprints}


A piece of digestive gland was used to prepare the imprints. After drying the tissues on absorbent paper, imprints were made on a glass slide. Slides were air - dried, fixed in absolute ethanol and then stained with Hemacolor@ Kit (Merck) in accordance with the manufacturer's instructions and examined microscopically.

\subsection{DNA extraction}

DNA extraction from oysters tissues was carried out as follows: digestive glands were added to a solution of extraction buffer ( Nacl 100mM, 10mMtris, pH: 8,25mM, EDTA pH 8, SDS $0,5 \%)$ with proteinase $\mathrm{K}(100 \mathrm{ug} / \mathrm{ml})$. Following an overnight incubation at $55^{\circ} \mathrm{C}$, DNA was extracted using a QIA amp DNA Mini-Kit (Qiagen) according to the manufacturer's instructions.

\subsection{PCR amplification}

Two PCR assays were used for the detection of Marteilia spp. in parasitized oysters. The first one was performed according to Le Roux et al. (2001) and amplified the ITS1 region of the parasite genome using $M$. refringens specific primers PR4 and PR5. The second one was a nested PCR assay targeting the IGS region (Lopez-Flores et al. 2004). DNA extracted from M. refringens purified cells was used as a positive control. Negative controls consisted of distilled water. PCR amplification program included: denaturation for $5 \mathrm{~min}$ at $94^{\circ} \mathrm{C}$, 30cycles of $94^{\circ} \mathrm{C}$ for $1 \mathrm{~min}, 55^{\circ} \mathrm{C}$ for $1 \mathrm{~min}$, and elongation for $1 \mathrm{~min}$ at $72^{\circ} \mathrm{C}$ with a final cycle of extension at $72^{\circ} \mathrm{C}$ for $10 \mathrm{~min}$.

\subsection{RFLP}

Marteilia refringens type was determined according to Le Roux et al. (2001) by digesting Pr4-Pr5 PCR products with HhaI (10U/ $\mu$ l, Promega) for at least one hour at $37^{\circ} \mathrm{C}$. Resulting fragment patterns were analyzed electrophoretically on $2 \%$ agarose gel.

\subsection{Sequencing}

Sequencing is recommended as one of the final steps for confirmation diagnosis of Marteilia refringens in a new host and/or a new location (OIE, 2011). Some samples found positive by 
PCR-ITS and PCR-IGS were selected for direct DNA sequencing. PCR products were purified by Qia quick PCR purification (Qiagen Inc). PCR products obtained for one oyster collected in 2010 were cloned using the TOPO TA cloning Kit (Invitrogen) according to manufacturer's recommendations and positive clones were then selected for plasmid DNA purification by FastPlasmid ${ }^{\circledR}$ Min (Ependorf). DNA suspensions or purified PCR products were sequenced using the Big Dye V3 sequencing Kit (Applied Biosystem, U.S.A.) and same PCR primers used for initial amplification. Obtained sequences were compared with those included inGenBanck using BLAST algorithm (Atschul et al. 1997).

\subsection{Phylogenetic analyses}

Some available ITS-1 sequences from Marteilia refringens were downloaded from GenBank and included in phylogenetic analysis with sequences obtained in the present study. ITS1 sequences from GenBank included some Marteilia refringens detected and characterized in Mytilus galloprovincialis (AJ62934, 38-40, 42-51, DQ426575, 80, 82, 83, 88, 92, 95, 99, DQ426602) in Ostrea edulis (AJ629334-37, DQ426605, 11, 16, 21, 26, 30, 35, 40) and in Cerastoderma edule (JN820085-9). Alignments were performed using Clustal W (Thompson et al. 1994) including in MEGA 5 with open and extend gap penalties of 15 and 8 respectively. Parsimony analyses were also conducted using MEGA version 5 (Tamura et al., 2011) with the close neighbour interchange (CNI) heuristic option. Bootstrap values were calculated over 1000 replicates and cut-off value for condensed tree was of $50 \%$.

\subsection{TEM}

From Five oysters found positive by cytology, a small size piece of digestive gland (1-2mm) was fixed in $3 \%$ glutaraldehyde for 1 hour, washed three times in filtered sea water (FSW), fixed in $1 \%$ osmic acid and washed twice again in FSW. After dehydration in successive baths of ethanol, and two baths of propylene oxide, samples were progressively impregnated and embedded in Epon. After polymerisation at $60^{\circ} \mathrm{C}$, semi-thin sections were cut to $1 \mu \mathrm{m}$ thickness for quality control and then to 80 to $85 \mathrm{~nm}$ for examination on leica ultracuts, floated onto copper EM grids and stained with uracyl acetate/ Fahmys lead citrate (Lewis \& Knight 1977). The sections were examined using an electron microscope (JEM 1010, JEOL) at 8KV.

\section{Results}


3.1 Selection of infected oysters for further characterization

207

208

209

210

PCR-ITS analysis of 103 O. stentina collected in 2009 from the Stah Jeber port (Monastir bay), in Tunisia, yielded amplicons with expected size (403 bp) in 85 oysters. Detection frequency appeared lower in June (21+/30Ind) and October (5+/13Ind) and higher in February $(30+/ 30)$ and March (28+/30. Some positive samples were tested by PCR-IGS. Five and two samples were selected for direct sequencing of the ITS1 and IGS regions respectively. Examination of digestive gland imprints for 20 oysters collected from Monastir in May 2010 revealed presence of parasites in eleven oysters. One sample was selected for sequencing ITS1 region after cloning. For the same sample, IGS PCR products were directly sequenced. Three of these samples were selected for transmission electron microscopy examination. Following the evolution of parasite infection depending on the season, the infection intensity was almost the same during the season.

\subsection{Molecular characterization of the parasite}

\subsubsection{RFLP}

Pr4-Pr5 PCR products obtained for 85 samples from 2009 and for 11 oysters from 2010 were digested with HhaI. Restriction profile corresponding to Marteilia refringens type O (226 bp; $156 \mathrm{bp} ; 31 \mathrm{bp}$ ) was obtained for 83 and 8 oysters collected in 2009 and 2010 respectively. Five PCR positive oysters did not allow obtaining comprehensive restriction profile because of faint PCR products.

\subsubsection{Sequence analysis}

In total, seven and three sequences were obtained for the ITS1 and IGS regions respectively. Comparison with DNA sequences included in GenBank database revealed 99\% of identity with Marteilia refringens ITS-1 sequences (e.g DQ426613, DQ426620, AY324588, DQ426644, AB513427) and $100 \%$ of identity with $M$. refringens IGS sequences (e.g AJ629355, AJ629356). Alignment of the seven obtained ITS1 sequences with one sequence available in GenBank for Marteilia refringens type M (DQ426599) and type O (DQ426611) is shown in Figure 2. 
240 All the obtained sequences had the same nucleotide $\mathrm{C}$ in position 257 demonstrating that only $M$. refringens type $\mathrm{O}$ was presently detected and sequenced. Indeed, this position is used to distinguish between $M$. refringens type $\mathrm{M}$ (displaying a $H$ haI restriction site in this position) and type $\mathrm{O}$.

Seven positions displayed polymorphism among sequences (Figure 2). Four of them consisted of transition ( $\mathrm{C}$ instead of $\mathrm{T}$ in position 18 and $\mathrm{G}$ instead of $\mathrm{A}$ at positions 64, 91 and 134). Positions 39 and 62 showed transversion (A instead of C) while positions 61 and 62 showed a insertion and deletion of C respectively. Two sequences (09 17611 and 10064 C3) showed the same polymorphism in positions 39,61 and 62 while other polymorphisms were generally observed in only one sequence.

Among the seven obtained sequences two of them were found twice, in two different samples (09 17611 identical to $10064 \mathrm{C} 3$ and 0917613 identical to 09176 15). Finally, the five different obtained sequences were deposited in the GenBank database under accession numbers (GenBank ID: JX 119018-22). The three IGS obtained sequences did not show polymorphism and were similar with a maximum identity of $100 \%$ with Marteilia refringens detected in flat oysters (AJ629355; AJ629353).

To determine the taxonomic affiliation of Marteilia refringens reported in the present study with other conspecific isolates, phylogenetic analysis was performed on the rRNA ITS1 region (Figure 3). All the type $\mathrm{O}$ sequences grouped together while our sequences appeared in the group of type $\mathrm{O}$ sequences (Figure 3). Sequences displaying HhaI restriction site specific to type $\mathrm{M}$ grouped together with a bootstrap value of $75 \%$. Curiously sequence DQ426583 appeared closer to type $\mathrm{M}$ sequences than to type $\mathrm{O}$ although predicted RFLP analysis classified it in type $\mathrm{O}$.

3.3 Cytological, histological and ultrastructural description of the parasite

\subsubsection{Digestive gland imprints}

Examination of digestive gland imprints from infected oysters allowed observing various parasite life cycle stages including daughter cells, immature and mature sporonts (Figure 4) 


\subsubsection{Histology}

275

Different parasite stages were observed in histology. In case of light infection, some primary stages could be detected in stomach epithelium (Figure 5A.). In more advanced infection, primary stages were located in digestive duct canals and more mature stages were observed in the epithelium of digestive tubules (Figure 5B.). In case of high infection, most of the digestive gland appeared affected and the presence of parasites, including zoosporangious was associated with haemocytic infiltration (Figure 5C).

\subsubsection{Ultrastructural characterization}

Both young stages and sporulating stages were observed in the same area of the digestive gland. Primary cells (C1) enclosing 1 to 3 visible secondary cells (C2) contained refringent granules and striated plate-like inclusions (figure 6, A). Older stages of Marteilia cells were observed within epithelial cells of digestive tubules. Initial cells (sporangiosorus) (S) (figure $6 \mathrm{~B}$, So) contained 4 to 6 visible secondary cells or presporangiosora (P). Each presporangiosorum (So) contained 2 sporangia with one to three visible immature spores (Sp). Advanced stages of spores formation could be observed with the building of spore wall by piling up several layers of membranes around the thicker spore membrane (figure $6 \mathrm{C}, \mathrm{W}$ ). Spores were made of 3 concentric sporoplasms the outer one or third cell containing numerous haplosporosomes (figure 6C, H). Sporoplasm from the intermediate sporal cells contained vermiforms vacuoles (figure $6 \mathrm{C}$ and $\mathrm{D}, \mathrm{V}$ ) roughly organized at right angle of the spore membrane. Peripheral infolding or invagination of the sporangium wall around the external sporal cells (figure $6 \mathrm{C}, \mathrm{Sw}$ ) and the large refringent bodies (figure $6 \mathrm{C}, \mathrm{Rb}$ ) were observed. Other pictures showed that this invagination leads to the cleavage of spores inside the sporangium. The spheroid haplosporosomes ranged from $77 \mathrm{~nm}$ to $123 \mathrm{~nm}$ diameter $(\mathrm{n}=$ $30)$, with a mean size of $97 \mathrm{~nm}$ (standard deviation $=13 \mathrm{~nm})$.

\section{Discussion}

Marteiliosis due to Marteilia refringens is a disease that causes serious recurring mortalities of the European flat oyster Ostrea edulis (Grizel et al., 1974a). The diagnosis of mollusk diseases usually relies on histology and cytology (including tissue imprints) but molecular 
tools are of the utmost importance, especially for species confirmation. We present herein the presence of marteiliosis in a new host species in a new study site. Indeed, microscopic evidence and DNA sequencing confirmed the presence of $M$. refringens in the dwarf oyster Ostrea stentina in Tunisia.

Ostrea stentina is an endemic oyster species in Tunisia which is not exploited notably because its small size. Despite of an intense reproductive cycle (Elgharsalli \& Aloui-bejaoui, 2011) and the lack of fishery pressure, this species appears endangered because of unexplained mortalities occurring since 2007 in Tunisia. Very little information is available concerning the health status of $O$. stentina along the Tunisian coasts. A previous study reported the presence of a parasite Bonamia exitiosa in some oysters (Hill et al. 2010), but the prevalence $(10,6 \%$ ) did not support a strong association between this protozoan and the observed mortality.

Recently, some oysters collected in 2009 and tested by PCR revealed the presence of Marteilia refringens DNA in $88 \%$ of the oysters while B. exitiosa DNA was detected in only $3 \%$ of them (unpublished results). These results suggested a possible involvement of $M$. refringens in the mortality of $O$. stentina. The purpose of the present study was not to assess its impact on dwarf oyster population in Tunisia but to better characterize the parasite in $O$. stentina using molecular tools, histological and ultrastructural observations.

Histological and cytological examinations of infected oysters revealed the presence of different parasite stages previously described in the literature in flat oysters Ostrea edulis (Grizel et al. 1974a) and mussels Mytilus galloprovincialis (Figueras et al. 1991; Villalba et al. 1993). In O. stentina, $M$. refringens displays a digestive tropism like in other bivalve hosts. Early stages were observed in the ciliated epithelium of the stomach while more mature stages containing refringent bodies, occured in the epithelium of the digestive tubules. High infection level appeared associated with high haemocytic infiltration.

Ultrastructural study confirmed the presence of stages already described by different authors in the Paramyxae and particularly in Marteilia refringens (Grizel et al. 1974b, Perkins 1976, Desportes 1984, Longshaw et al. 2001). The primary cells and the advanced sporulation stages were similar to the one previously described in $M$. refringens parasites infecting the European flat oyster Ostrea edulis and the mussels Mytilus edulis and M. galloprovincialis in Europe (Comps 1985, Villalba et al., 1993; Longshaw et al. 2001). The spores characteristics 
are in accordance with the previously described characteristics of $M$. refringens spores in $O$. edulis (Grizel et al. 1974a, Comps 1985, Longshaw et al. 2001) and of M. refringens (=M. maurini) in the mussel M. galloprovincialis from Mediterranean (Comps et al. 1981) with the intermediate sporal cell and the inner sporal cell being created by endosporulation of the third cell (Perkins 1976, 1979, Desportes 1984). Haplosporosomes appeared closer in size to haplosporosomes described in M. refringens infecting O. edulis (Perkins 1976, Longshaw et al. 2001) but smaller to the ones observed in M. refringens infecting M. galloprovincialis $(130-200 \mathrm{~nm})$ in Spain (Robledo \& Figueras 1995) or M. edulis (130-160 nm) in France (Auffret \& Poder 1983).

Finally ITS-1 and IGS sequences did not allow distinguishing between Marteilia refringens infecting $O$. stentina in Tunisia and other $M$. refringens detected in Europe. Indeed our sequences showed 99 to $100 \%$ of identity with $M$. refringens type O previously detected and characterized in mussels Mytilus galloprovincialis (Lopez-Flores et al. 2004, Novoa et al. 2005) and O. edulis (Le Roux et al. 2001, Lopez-Flores et al. 2004, Novoa et al. 2005). ITS1 sequences obtained from different clones from a same oyster or from different oysters collected at different dates (2009 and 2010) showed several polymorphous sites but grouped together with sequences available for $M$. refringens type $\mathrm{O}$ in GenBank (figure 3). Type definition is based on a dimorphism corresponding to a HhaI restriction site in the ITS-1 region (Le Roux et al. 2001). The phylogenetic analysis conducted on some sequences available in GenBank and our sequences showed a good concordance between types and groups of sequence except for one sequence which appeared closer to type $\mathrm{M}$ group although RFLP expected profile would classify it as type O. Altough many previous detection of the parasite did not include molecular characterization, type $\mathrm{O}$ has been more often associated with $O$. edulis and type $\mathrm{M}$ with Mytilus spp. than the contrary.

Marteilia refringens has previously been reported in different European countries and in the Mediterranean basin including Spanish, Morrocan, Greek, Croatian, Slovenian, Italian and French coasts. Its first detection in Tunisia and in a new oyster species, Ostrea stentina enlarges the host range and geographic distribution of this parasite which seems to be able to infect a wide range of bivalve species. The distribution of the dwarf oyster $O$. stentina includes the southern Mediterranean coasts, southwestern coast of the Iberian Peninsula and the African coasts as far as South Africa (Ranson, 1967). Considering that O. stentina and $O$. 
edulis are sympatric in some areas (Leal 1984; Lapegue et al. 2006), it is important that surveillance of marteiliosis includes these two susceptible oysters species when they cohabit.

Based on our results, Ostrea stentina should be included in the list of susceptible species to the infection with Marteilia refringens. However further studies are required to determine the actual spread of the parasite in this oyster species in other locations and to investigate the impact of the parasite on population of $O$. stentina.

\section{Acknowledgments}

This research was supported by a grant from the Ministry of Higher Educative, Scientific research and Technology of Tunisia. Jean Prou and Tristan Renault are acknownledged as heads of IFREMER- La Tremblade Station and Laboratoire de Génétique et Pathologie respectively, for having allowed visit studies in France. We thank Dr Arnaud Huvet from Laboratoire de Pathologie des Invertébrés, IFREMER Brest for having provided DNA suspensions from first samples collected in 2009.

\section{Figure captions}

Figure 1. Ostrea stentina. Study site: Stah Jeber port: Monastir Bay, the east coast of Tunisia.

Figure 2. Alignement of seven obtained ITS1 sequences from infected Ostrea stentina with Marteilia refringens type M (DQ426599) and type O (DQ426611) sequences available under GenBank. Nucleotidic positions that distinguishes between type $\mathrm{M}$ and type $\mathrm{O}$ using HhaI digestion is boxed.

Figure 3. Maximum parsimony analysis of ITS 1-rDNA sequences (1000 replicates) showing the position of Marteilia refringens sequences infecting Ostrea stentina obtained in this study. Numbers at each node correspond to bootstrap values. The analysis involved 46 nucleotide sequences. There were a total of 301 positions in the final dataset. 
Figure 4. Hemacolor (Merck) stained tissue imprints of the digestive gland of Ostrea stentina infected with $M$. refringens, showing various lifecycle stages (arrows) including daughter cells (Dc), immature sporonts (ImSp), and mature sporonts (MSp).

Figure 5. Hematoxylin and Eosin stained histological sections of Ostrea stentina infected with $M$. refringens, showing various lifecycle stages including primary stages (SI), secondary and tertiary stages (SII) and refringens stages (RS). (A) Primary stages in the ciliated epithelium of the stomach (B) different parasite stages in the epithelium of digestive duct canals (C) Digestive tubules infected with $M$. refringens and associated haemocytic infiltration.

Figure 6. TEM micrographs of digestive gland tubules from Ostrea stentina. (A) Primary cell $\mathrm{C} 1$ containing two secondary cells or presporangia $\mathrm{C} 2$ and striated plate-like inclusions in the cytoplasm (C : host cell). Note the two sporangiosora $\mathrm{S}$ containing presporangiosora close by (scale bar $=5 \mu \mathrm{m}$ ). (B) Sporangiosorus $\mathrm{S}$ containing at least 5 visible presporongiosora $\mathrm{P}$ with immature spores Sp. R: reticulated cytoplasm of sporangium So; Rb: refringent body (scale bar $=5 \mu \mathrm{m})$. (C) A sporangium So with an immature spore containing numerous haplosporosomes $\mathrm{H}$. The external sporal cell Sp1 and the intermediate sporal cell Sp2 are visible. Vermiform vacuoles $\mathrm{V}$ can be seen close to the intermediate sporal cell membrane. The sporangium contains a well developed refringent granule $\mathrm{Rg}$ close to the invaginated sporangium wall $\mathrm{Sw}$. Spore wall $\mathrm{W}$ is being built by piling up several membranes around the thicker spore membrane (scale bar $=2 \mu \mathrm{m}$ ). (D) An almost mature spore with intermediate sporoplasm S2 and innermost sporoplasm S3. S1: outermost sporoplasm containing numerous haplosporosomes $\mathrm{H}$; V: flattened vesicles in the intermediate sporoplasm; W: spore wall (scale bar $=1 \mu \mathrm{m})$.

\section{References}

- Altschul, S. F., Madden, T. L., Schaffer, A. A., Zhang, J., Zhang, Z., Miller, W. and Lipman, D. J., 1997. Gapped BLAST and PSI-BLAST: a new generation of protein data base search programs. Nucleic Acids Res. 25, 3389-3402.

- Audemard C, Barnaud A, Collins CM, Le Roux F, Sauriau PG, Coustau C, Blachier P, Berthe FCJ., 2001. Claire ponds as an experimental model for Marteilia refringens life-cycle studies: new perspectives. J. Exp. Mar. Bio. Eco. 257, 87-108. 
- Audemard C, Le Roux, F., Barnaud, A., Collins, C., Sautour, B., Sauriau, P-G, De Montaudouin, X., Coustau, C., Combes, C., Berthe, F., 2002. Needle in a haystack: involvement of the copepoda Paracartia grani in the life-cycle of the oyster pathogen Marteilia refringens. Parasitology. 124, 315-323.

- Auffret M., Poder M., 1983. Recherches sur Marteilia maurini, parasite de Mytilus edulis sur les côtes de Bretagne nord. Rev. Trav. Inst. Pêches Marit. 47, 105-109.

- Balseiro P, Montes A, Ceschia G, Gestal C, Novoa B, Figueras A., 2007. Molecular epizootiology of the European Marteilia spp., infecting Mussels (Mytilus galloprovincialis and M. edulis) and oysters (Ostrea edulis): an update. Bull. Fish. Patho. 27, 148-156.

- Berthe F., Le Roux F., Adlard R. \& Figueras A., 2004. Marteiliosisin molluscs: a review. Aquat. Living Resour. 17, 433 - 448.

- Bougrier S., Tigé G., Bachère E., Grizel H., 1986, Ostrea angasi acclimatization to French coasts. Aquaculture. 58, 151-154.

- Carrasco N. Arzul I. Berthe F. C. J. and M. D., 2008. In situ hybridization detection of initial infective stages of Marteilia refringens (Paramyxea) in its host Mytilus galloprovincialis. J. Fish Diseases. 31, 153-157.

- Carrasco, N., A. Roque, K.B. Andree, C. Rodgers, B. Lacuesta and M.D. Furones., 2011. A Marteilia parasite and digestive epithelial virosis lesions observed during a common edible cockle Cerastoderma edule mortality event in the Spanish Mediterranean coast. Aquaculture 321, 197-202.

- Carrasco, N., K.B. Andree, B. Lacuesta, A. Roque, C. Rodgers and M.D. Furones., 2012. Molecular characterization of the Marteilia parasite infecting the common edible cockle Cerastoderma edule in the Spanish Mediterranean coast. A new Marteilia species affecting bivalves in Europe. Aquaculture 324-325, 20-26.

- Carriker, M.R., Gaffney, P.M., 1996. A catalogue of selected species of living oysters (Ostreacea) of the world. In: Kennedy, V.S., Newell, R.I.E., Eble, A.F. (Eds.). The Eastern Oyster Crassostrea virginica. Maryland Sea Grant. College Park. Maryland, pp. 1-18.

- Cavalier-Smith T., 1998. A revised six-kingdom system of life. Biol. Rev. Camb. Phil. Soc. 73, 203-266.

- Cavalier-Smith, T. \& Chao, E. E., 2003. Phylogeny and classification of phylum Cercozoa (Protozoa). Protist. 154, 341-358. 
- Ceschia, G., Zanchetta, S., Sello, M., Montesi, F., Antonetti, P. and Figueras, A., 2001. Presence of parasites in razor clam (Ensis minor and Ensis siliqua) harvested from coastal areas of the southern Tyrrhenian and Adriatic Seas. Boll. Soc. Ital. Patol. Ittica. 13, 20-27.

- Comps M., 1983. Etude morphologique de Marteilia christenseni sp.N. parasite du lavignon Scrobicularia piperata P. (Mollusque Pelecypode). Rev. Inst. pêches Marit. 47, 99-104.

- Comps M., 1985. Digestive gland disease of the oyster. Maladie de la glande digestive de l'huître plate. International Council for the Exploration of the Sea. Copenhagen (Denmark). identif. Mal. Parasit. Poissons Crustacés Mollusques Fich. 5 : 19 p.

-Comps M., 1976, Marteilia lengehi n. sp., parasite de l'huître Saccostrea cucullata Born. Rev. Trav. Inst. Pêches Mar. 40, 347-349.478.

-Comps M., Grizel H., Tigé G., Duthoit J.L., 1975. Parasites nouveaux de la glande digestive des mollusques marins Mytilus edulis L. et Cardium edule. C.R. Acad. Sci. Paris Série D. 281, 179-181.

- Comps, M., Y. Pichot and P. Papagianni., 1981. Research on Marteilia maurini n. sp. parasite of the mussel Mytilus galloprovincialis Lmk. Rev. Trav. Inst. Pêches Marit. 45, 211214.

- Desportes I., 1984. The Paramyxea Levine., 1979. An original example of evolution towards multicellularity. Origins of Life. 13, 343-352.

- Elgharsalli R. \& Aloui B. N., 2011. First study in the Mediterranean of gametogenesis of the Oyster Ostrea stentina (Payraudeau, 1826) in the gulf of Hammamet. Cah. Biol. Mari. 52, 157- 169.

- Feist AM, Herrgard MJ, Thiele I, Reed JL, Palsson BO., 2009. Reconstruction of biochemical networks in microorganisms. Nat. Rev. Microbiol. 7, 129-143.

- Figueras A.J., Jardon C.F., Caldas J.R., 1991. Diseases and parasites of rafted mussels (Mytilus galloprovincialis Lmk): preliminary results. Aquaculture. 99, 17-33.

- Figueras A.J., Montes J., 1988. Aber disease of edible oysters caused by Marteilia refringens. Am. Fish. Soc. Spec. Publ. 18, 38 - 46.

- Grizel H, Comps M, Bonami JR, Cousserans F, Duthoit JL, Le Pennec MA., 1974. Recherche sur l'agent de la maladie de la glande digestive d'Ostrea edulis Linne. Sci Pêche, Bull. Inst. Pêches Marit. 240, 7-29.

- Grizel H., Comps M., Cousseraris F., Bonsami J.R., Vago C., 1974 a. Etude d'un parasite de la glande digestive observé au cours de l'épizootie actuelle de l'huître plate C. R. Acad. Sci. Série D. Paris. 279, 783-784. 
- Grizel H., Comps M., Raguenes D., Le Borgne Y., Tigé G., Martin A.G., 1983. Bilan des essais d'acclimatation d'Ostrea chilensis sur les côtes de Bretagne. Rev. Trav. Inst. Pêches Marit. 46,209-225.

- Harry H.W., 1985. Synopsis of the Supraspecific Classification of living oysters, (Bivalvia: Gryphaeidae and Ostreidae). The Veliger. 28, 121-158.

- Hill K.M., Carnegie R.B., Bejaoui N.A., El Gharsalli R., White D.M., Stokes N.A. \& Burreson E.M., 2010. Observation of a Bonamia sp. infecting the oyster Ostrea stentina in Tunisia, and a consideration of its phylogenetic affinities. J. Inver. Patho. 103, 179-85.

- Ikram I. Sabiha T.Z and Oum Kalthoum B.H., 2007. Etude de la faune associée à l'espèce invasive Pinctada radiata sur le littoral nord et est de la Tunisie. Rapp. Comm. int. Mer Medit. 38, 503.

- Lapègue S., Salah I.B., Batista F.M., Heurtebise S., Neifar L. \& Boudry P. 2006. Phylogeographic study of the dwarf oyster, Ostreola stentina, from Morocco, Portugal and Tunisia: evidence of a geographic disjunction with the closely related taxa, Ostrea aupouria and Ostreola equestris. Mar. Bio. 150, 103-110.

- Le Roux F, Lorenzo G, Peyret P, Audemard C, Figueras A, Vivares C, Gouy M, Berthe F., 2001. Molecular Evidence for the Existence of Two Species of Marteilia in Europe. J. Euk. Microbio. 48, 449 - 454.

- Leal A.M., 1984. Estado actual das ostreiras dos estuarios do Tejo, Sado, Mira e do Algarve. In INIP/APRH (eds) Seminario sobre aquacultura Lisboa, pp 71-86.

- Lewis, P.R. \& Knight, D.P., 1977. Staining methods for sectioning material. In: Practical Methods in Electron Microscopy (A.M. Glauert, Ed.), North Holland. Amsterdam.

- Longshaw M, Feist SW, Matthews A, Figueras A., 2001. Ultrastructural characterisation of Marteilia species (Paramyxea) from Ostrea edulis, Mytilus edulis and Mytilus galloprovincialis in Europe. Dis Aquat. Org. 44, 137-142.

- Lopez-Flores I, de la Herran, R., Garrido-Ramos, MA., Navas, JI., Ruiz-Rejon, C., Ruiz Rejon, M., 2004. The molecular diagnosis of Marteilia refringens and differentiation between Marteilia strains infecting oysters and mussels based on the rDNA IGS sequence. Parasitology. 129, 411-419.

- López-Flores, I., F. Robles, J.M. Valencia, A. Grau, A. Villalba, R. de la Herrán, M.A. Garrido-Ramos, C. Ruiz-Rejón, M. Ruiz-Rejón and J.I. Navas., 2008b. Detection of Marteilia refringens using nested PCR and in situ hybridisation in Chamelea gallina from the Balearic Islands (Spain). Dis. Aquat. Org. 82, 79-87. 
- López-Flores, I., M.A. Garrido-Ramos, R. de la Herran, C. Ruiz-Rejón, M. Ruiz-Rejón and J.I. Navas., 2008a. Identification of Marteilia refringens infecting the razor clam Solen marginatus by PCR and in situ hybridization. Mol. Cell. Probes. 22, 151-155.

- Novoa, B., Posada, D., Figueras, A., 2005. Polymorphisms in the sequences of Marteilia internal transcribed spacer region of the ribosomal RNA genes (ITS-1) in Spain: genetic types are not related with bivalve hosts. J. Fish. Dis. 28, 331-338.

- OIE. Office International des Epizooties., 2011. Aquatic animal health code, 79th edn. OIE, Paris.

- Pascual M., Martin A.G., Zampatti E., Coatanea D., Defossez J., Robert R., 1991, Testing of the Argentina oyster, Ostrea puelchana in several French oyster farming sites. ICES Council Meeting. Shellfish Comm. Copenhagen, Denmark. CM 1991/K, 30.

- Pascual S., A. Villalba, E. Abollo, M. Garci, A. F. González, M. Nombela, D. Posada and A. Guerra., 2010. The mussel Xenostrobus securis: a well-established alien invader in the Ria de Vigo (Spain, NE Atlantic). Biological Invasions. Volume 12, Number 7, 2091-2103.

- Payraudeau, B.C., 1826. Catalogue descriptif et méthodique des annélides et de mollusques de l'Isle de Corse. Paris.

- Perkins F.O., 1976. Ultrastructure of sporulation in the European flat oyster pathogen, Marteilia refringens - Taxonomic implications. J. Protozol. 23, 64-74.

- Perkins F.O., 1979. Cell structure of shellfish pathogens and hyperparasites in the genera Minchinia, Urosporidium, Haplosporidium, and Marteilia: Taxonomic implications. Mar. Fish. Rev. 41, 25-37.

- Poder M., Auffret M., Balouet G., 1983. Études pathologiques et épidémiologiques des lésions parasitaires chez Ostrea edulis: Premiers résultats d'une recherche prospective comparative chez les principales espèces de mollusques des zones ostréicoles de Bretagne nord. Bases biologiques de l'aquaculture, Montpellier, 12-16 décembre, 125-138.

- Ranson G., 1967. Les espèces d'huîtres vivant actuellement dans le monde, définies par leurs coquilles larvaires ou prodissoconques. Rev. Trav. Inst. Pêches marit. 31, 1-146.

- Renault T., Cochennec N., Chollet B., 1995. Marteiliosis in American oysters Crassostrea virginica reared in France. Dis. Aquat. Org. 23, 161-164.

- Robledo J.A.F., Figueras A.J., 1995. The effects of culture-site, depth, season and stock source on the prevalence of Marteilia refringens in cultured mussels (Mytilus galloprovincialis Lmk.) from Galicia. Spain. J. Parasitol. 81, 354-363. 
569 - Robledo, J.A.F., Santarem, M.M., González, P. and Figueras, A., 1995. Seasonal variations 570 in the biochemical composition of the serum of Mytilus galloprovincialis Lmk. and its

571 relationship to the reproductive cycle and parasitic loads. Aquaculture. 133, 311-322.

572 - Seurat L.G., 1934. Formations littorales et estuaires de la Syrte mineure (golfe de Gabès).

573 Bulletin de l'institut National des sciences et Technologies de la Mer de salammbô, 32: 1-65.

574 - Tamura, K., D. Peterson, N. Peterson, G. Stecher, M. Nei and S. Kumar., 2011. MEGA5:

575 Molecular evolutionary genetics analysis using maximum likelihood, evolutionary distance

576 and maximum parsimony methods. Mol. Biol. Evol. 28, 2731-2739.

577 - Thompson JD, Higgins DG, Gibson TJ. 1994. CLUSTAL W: improving the sensitivity of 578 progressive multiple sequence alignment through sequence weighting, position specific gap 579 penalties and weight matrix choice. Nucleic Acid. Res. 22, 4673-4680.

580 - Villalba A., Mourelle S.G, Carballal M.J, Lopez M.C., 1993b. Effects of infection by the 581 protistan parasite Marteilia refringens on the reproduction of cultured mussels Mytilus 582 galloprovincialis in Galicia (NW Spain). Dis. Aquat. Org. 17, 205-213.

583 - Villalba A., Mourelle S.G, López M.C, Carballal M.J., Azevedo C., 1993. Marteiliasis 584 effecting cultured mussels Mytilus galloprovincialis of Galicia (NW Spain). Etiology, phases 585 of the infection, and temporal and spatial variability in prevalence. Dis. Aquat. Org. 16, 6158672. 


\section{List of figures}

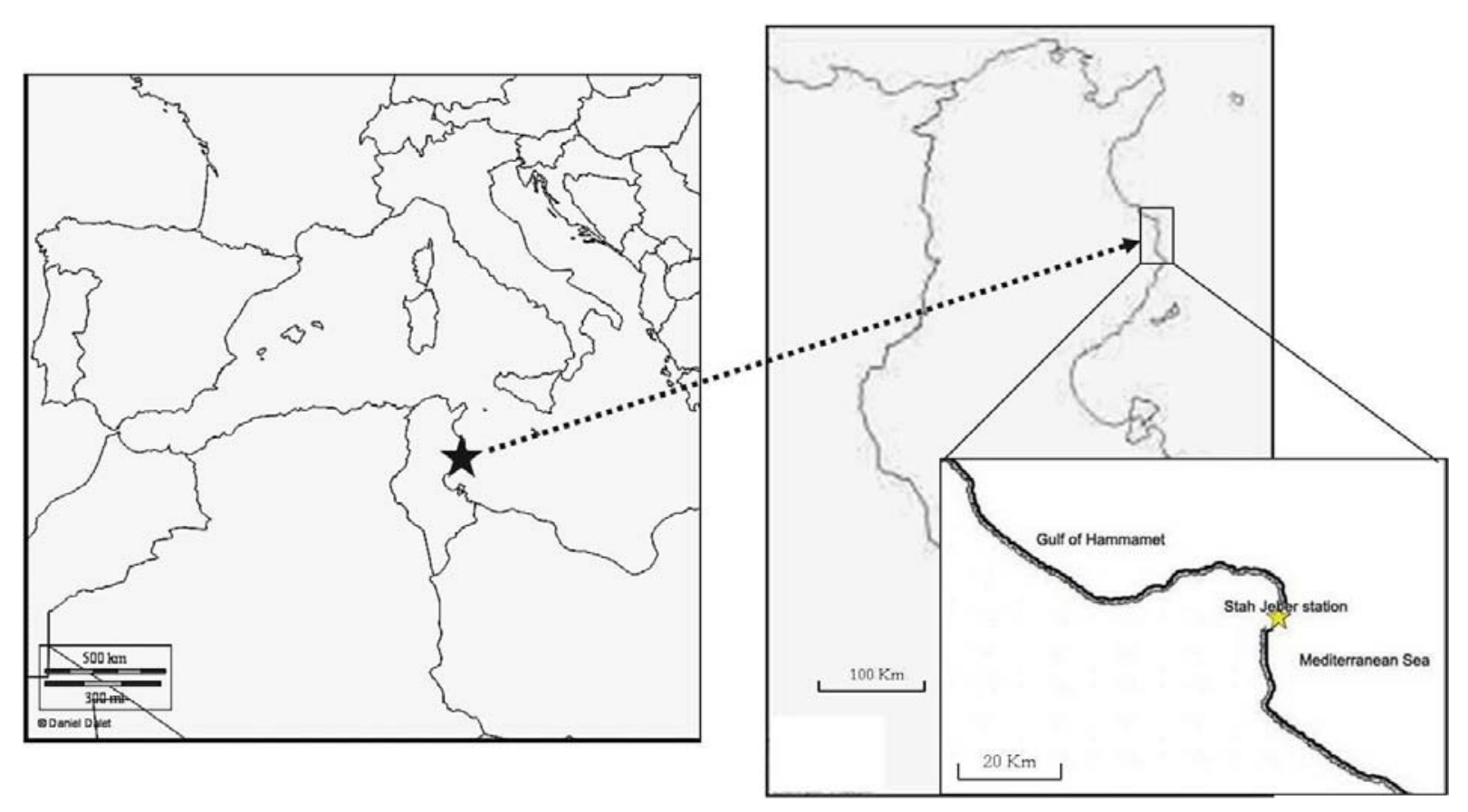

Figure 1. Ostrea stentina. Study site: Stah Jeber port: Monastir Bay, the east coast of Tunisia.
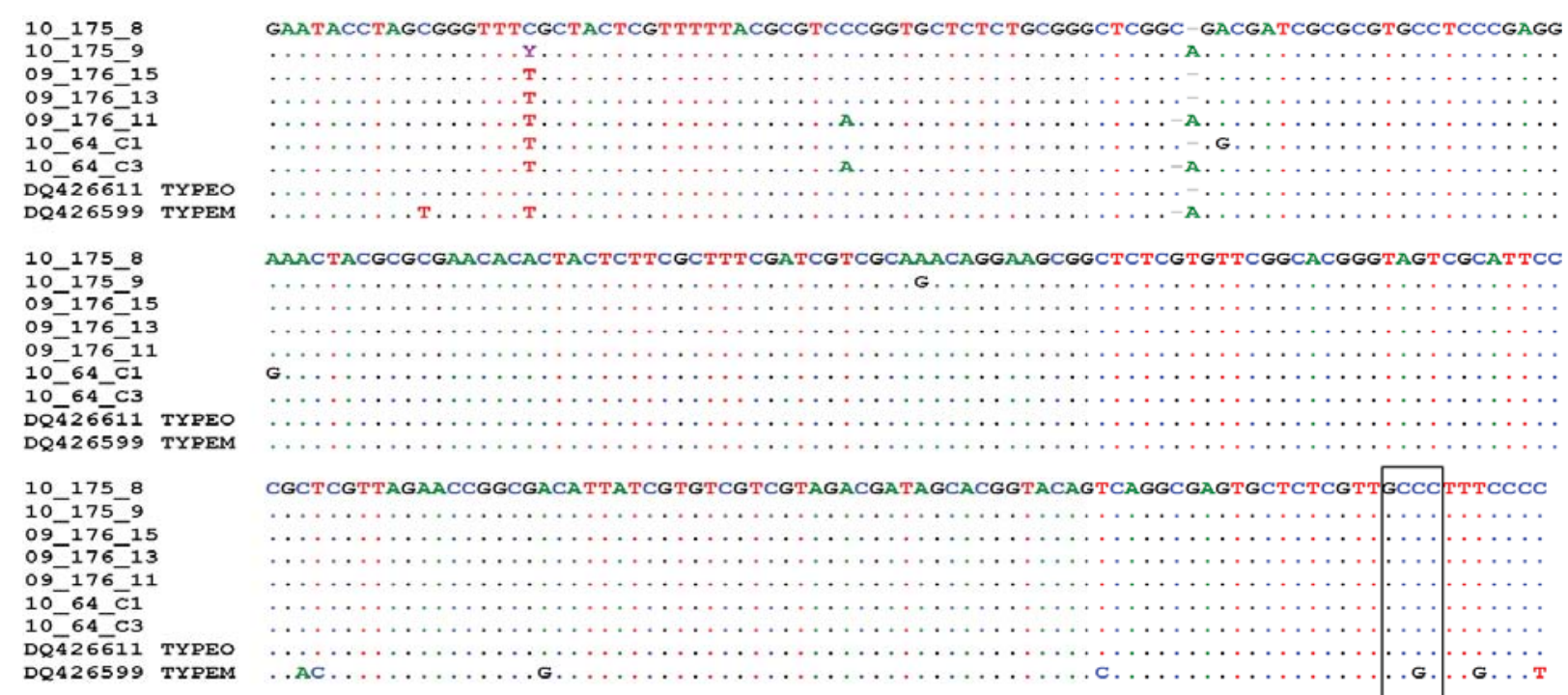

AAACTACGCGCGAACACACTACTCTTCGCTTTCGATCGTCGCAAACAGGAAGCGGCTCTCGTGTTCGGCACGGGTAGTCGCATTCC

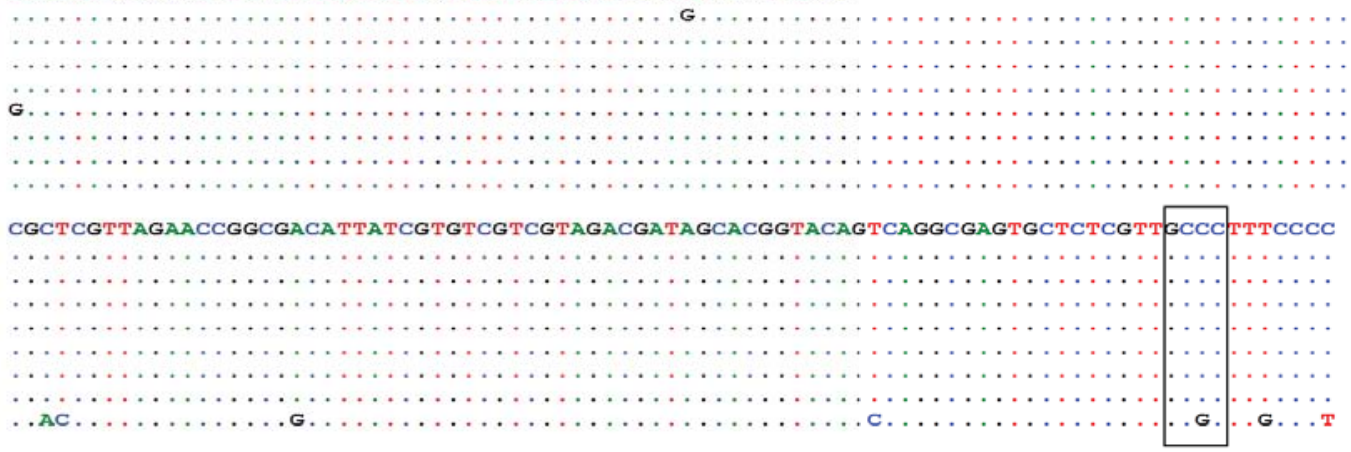

Figure 2. Alignement of seven obtained ITS1 sequences from infected Ostrea stentina with Marteilia refringens type $\mathrm{M}$ and type $\mathrm{O}$. 


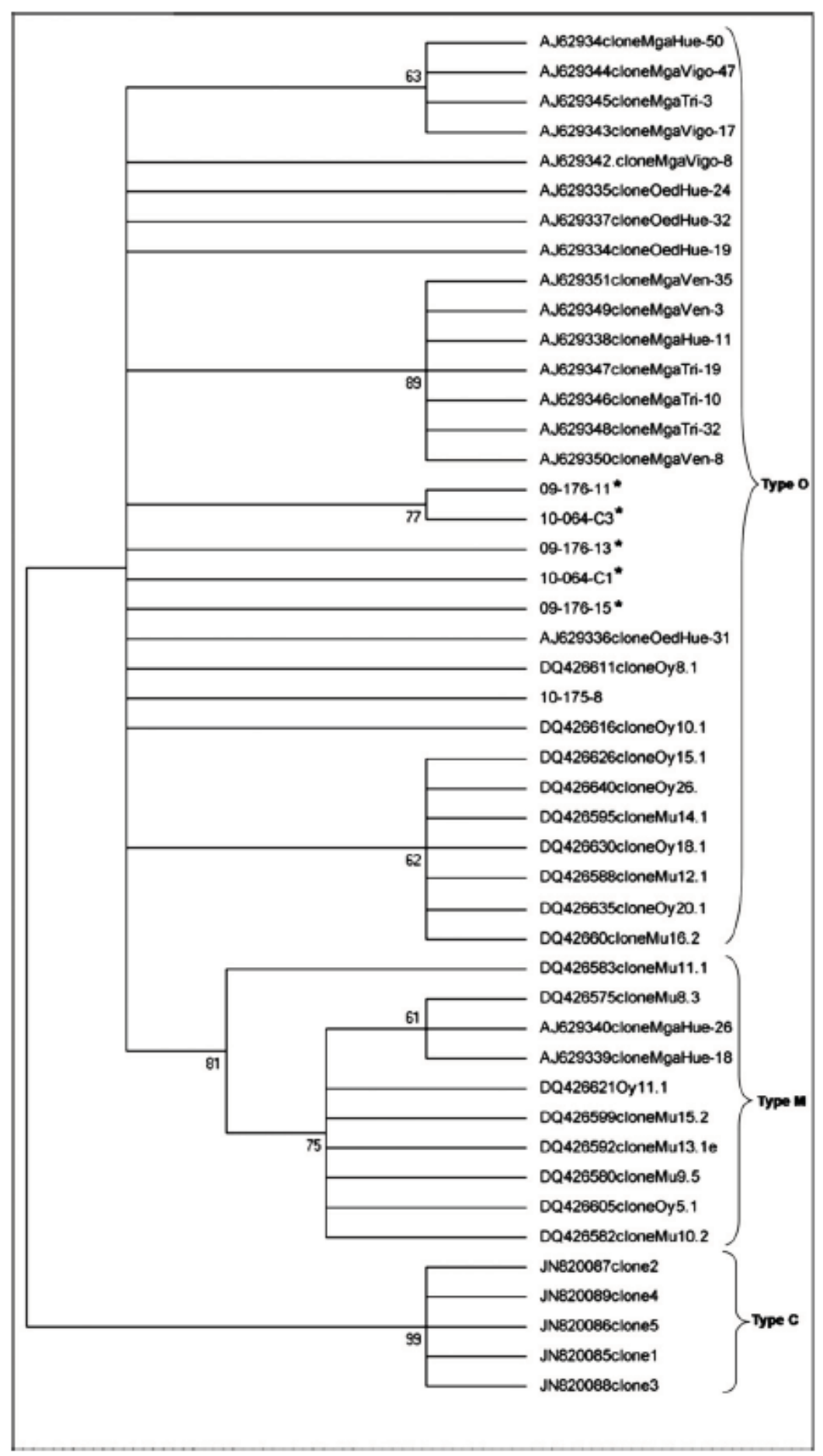

Figure 3. Maximum parsimony analysis of ITS 1-rDNA sequences (1000 replicates) showing the position of Marteilia refringens sequences infecting Ostrea stentina obtained in this study. 

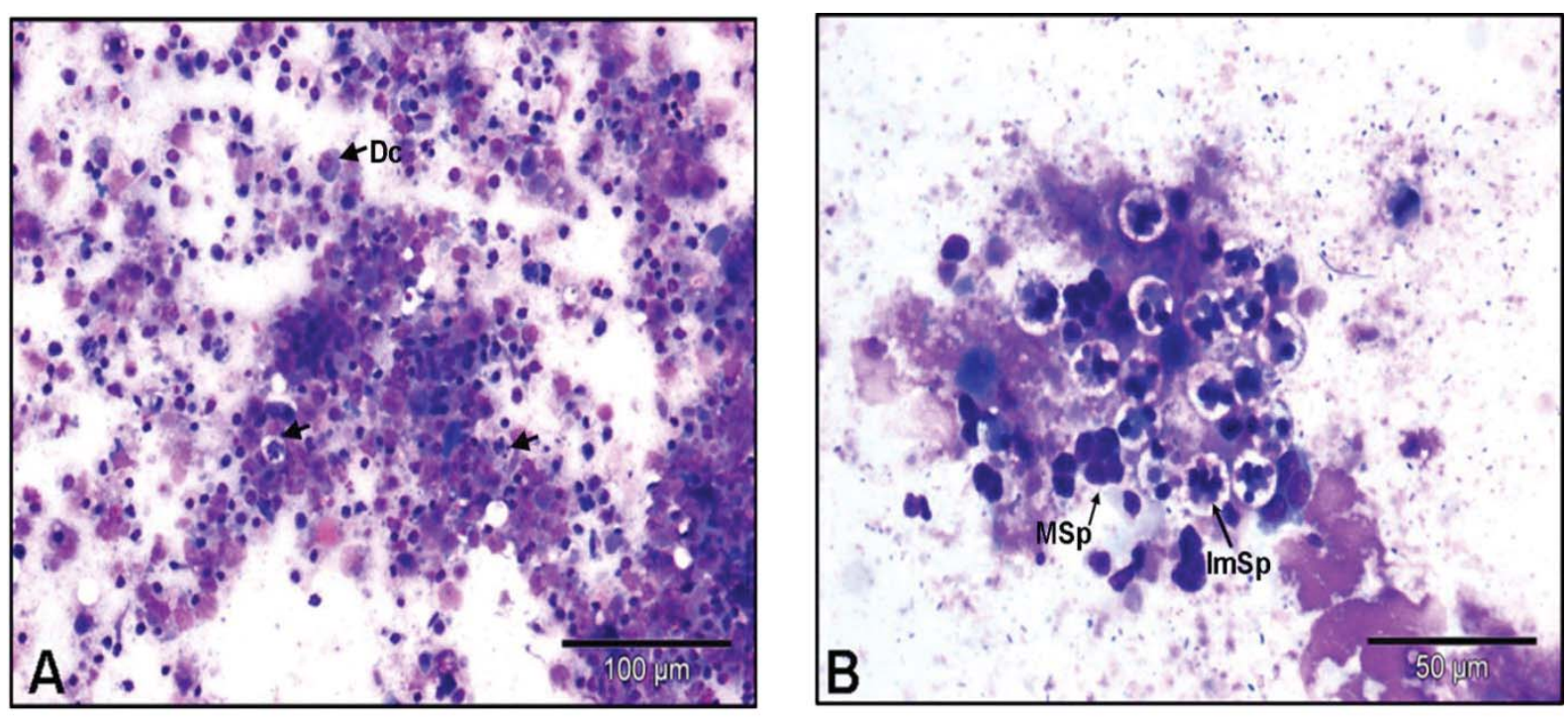

Figure 4. Hemacolor (Merck) stained tissue imprint of the digestive gland of Ostrea stentina infected with $M$. refringens.
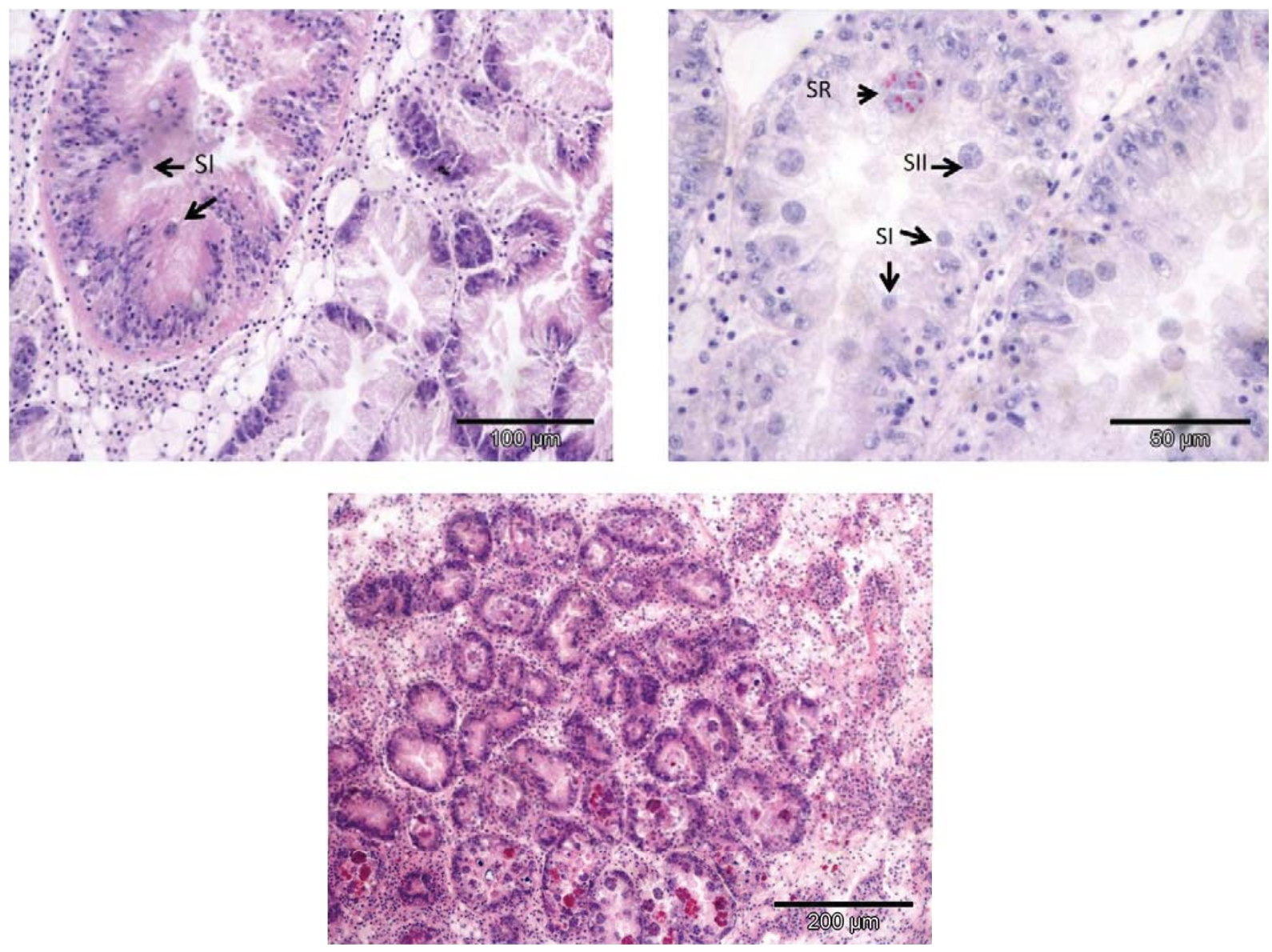
Figure 5. Hematoxylin and Eosin stained histological sections of Ostrea stentina infected with $M$. refringens.
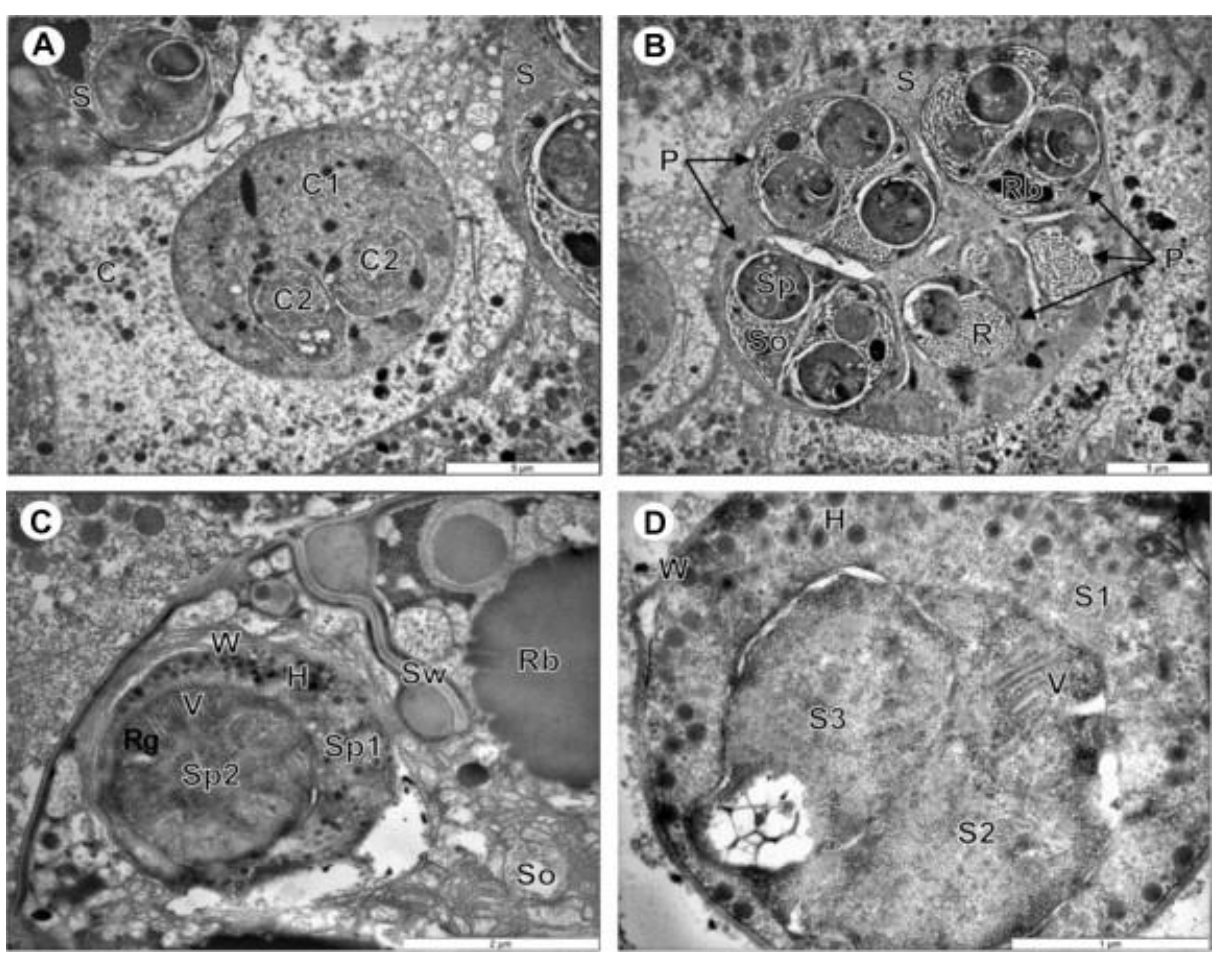

Figure 6. TEM micrographs of digestive gland tubules from Ostrea stentina . 